International Journal of Applied Linguistics \& English Literature

ISSN 2200-3592 (Print), ISSN 2200-3452 (Online)

Vol. 1 No. 4; September 2012

\title{
An Investigation into the Modality Specificity of L2 Learners' STM Abilities in Learning Vocabulary via PDAs
}

\author{
Saeed Khazaie (Corresponding author) \\ Faculty of Literature and Humanities, Shahid Chamran University of Ahvaz \\ Ahvaz, Iran \\ Tel: +989131861968Ｅ-mail: saeed.khazaie@gmail.com \\ Mohsen Jannejad \\ Faculty of Literature and Humanities, Shahid Chamran University of Ahvaz \\ Ahvaz, Iran \\ Tel: +989161116068_E-mail:m_jannejad@yahoo.com \\ Zahra Ahmadpour Kasgari \\ Faculty of Literature and Humanities, Shahid Chamran University of Ahvaz \\ Ahvaz, Iran \\ Tel: +989112119533E-mail: saraahmadpour@yahoo.com
}

Received: 05-06- 2012

doi:10.7575/ijalel.v.1n.4p.86
Accepted: 16-07- 2012

Published: 01-09- 2012

\begin{abstract}
Parallel with the rapid growth of wireless technology and potentials of mobile learning for language teaching/learning, employing mobile devices in language learning seems indispensable. To this end, designing learning materials suitable for different types of mobile devices regarding dual coding (DCT) and cognitive load (CLT) theories seems inevitable. In this study, multimedia were employed for designing two types of learning materials. Since short-term memory plays an important role in language learning, learners' visual and verbal short-term memories were taken into consideration, too. 161 L2 Learners aged 19 and 23 years old participated in the major phases of an experiment via personal digital assistant (PDA). Based on their scores on the English vocabulary recognition and recall (EVRR) tests and the statistical analysis of the results, it was revealed that delivery of learning materials with pictorial and written annotations combined rather than delivery of learning materials without such annotations to learners with high-visual and high-verbal abilities, learners with high-visual but low-verbal ability, and learners with low-visual but high-verbal ability results in better vocabulary learning outcomes. However, this was not the case for learners with low-visual and low-verbal abilities. This study acknowledges the relation between STM and the relevant modalities of materials presentation.
\end{abstract}

Keywords: Mobile learning, PDA, Verbal and visual ability, Vocabulary learning

\section{Introduction}

Among all mobile devices such as cell-phones, Personal Digital Assistants (PDAs), smart phones, etc., cell-phones are probably the most popular and widely used all over the world (Cui \& Wang, 2008). The United Nations (2010) reported that some 4.6 billion people are now cell-phone subscribers, indicating that 67 percent of all the people in the world are affected. Now cell-phone has not only become an entertainment device (featuring functions such as camera, FM and MP3 players, etc.) but also allows users to access the Internet, Personal Digital Assistant (PDA) functions and has video conferences using the state-of-the-art 3G (third generation of mobile phones) network. 
Due to these rapid advances in mobile technology, it seems that in future this technology could replace computers. Consequently, many researchers have started to believe that mobiles are not only able to support formal and informal learning but also to complete the process of learning via computers.

Moreover, since learning English is very popular in non-English speaking countries, developing modern assisted-learning tools that support effective English learning is a critical issue in English-language education (Chen, Ch.-M. \& Chung, 2008).

However, advances in the application of mobile technologies in language learning and teaching necessarily involve, in the early phases, a challenging process of trial and error, as teachers seek to incorporate new technologies into their students' already complex language-learning lives (Conacher, 2009). According to Bull and Kukulska-Hulme (2009), there is a large body of research on second language learning, but often much of the relevant theory and empirical findings are overlooked by developers of language learning technology support.

Chen, N.-S., Hsieh, and Kinshuk (2008) quoting Alavi and Leidner (2001) reported that a majority of previous studies have mainly relied on the stimulus-response theory, which probes only the relationship between information technologies (stimulus) and learning outcome (response); future studies should also take learner's characteristics into consideration in assessing the learning outcome of technology-mediated learning. They also pointed out that the Psychological Learning Process (PLP) of learners is an important mediator that cannot be neglected.

Information is cognitively processed through visual or verbal channels (Jones 2004; Mayer, 1979, 2005; Paivio, 1986). The basic architecture of information processing model is the Multi-store model (Atkinson \& Shiffrin, 1968) which consists of three types of memory: Sensory, Short-Term (STM), and Long-Term (LTM). There are studies about relation between vocabulary acquisition and verbal short-term memory (Gupta \& Mac Whinney, 1977; Greffe, Linden, Majerus, \& Poncelet, 2005).

Working memory is a more contemporary term for short-term memory which conceptualizes memory not as a passive system for temporary storage but as an active system for temporarily storing and manipulating information needed in the execution of complex cognitive task (e.g., learning, reasoning, and comprehension) (Richards \& Schmidt, 2002).Working memory is heavily involved in language learning (Ellis, 1996). In addition, according to Numminen (2002) working memory is an especially significant memory area for learning to read.

Also, in second or foreign language learning, different learners may prefer different solutions to learning problems. For example, some may want explanations for grammatical rules others may not need explanations. Some may feel that writing down words or sentences helps them to remember them. Others may find that they remember things better if they are associated with pictures. These are called differences of cognitive style (Richards \& Schmidt, 2002).

In designing learning material for PDAs, the application of multimedia seems useful through which, not only could different types of learning materials in the form of annotations be delivered to learners with different cognitive styles but also the limitation of screen size of PDAs could be solved to some extent.

Research on second language (L2) vocabulary acquisition has revealed that words associated with actual objects or imagery techniques are learned more easily than those without. With multimedia application, it is possible to provide, in addition to traditional definition of words, different types of information, such as pictures and videos (Chun \& Plass, 1996). The presence of both pictorial and written cues can facilitate learning, in particular when the corresponding visual and verbal representations are contiguously present in working memory (Mayer 2002, 2003). According to Jones (2004), researchers have long been interested in examining the effects of pictorial and verbal cues on L2 vocabulary learning, and have found that processing supportive information such as pictures or translations enhance language learning.

It seems suitable to take into consideration those aspects and theories such as cognitive theory of multimedia and cognitive load theory in applying multimedia in designing learning materials. The case for multimedia is based on the fact that instruction messages should be designed in the light of how human mind works (Mayer, 2005, p.54).

According to cognitive theory of multimedia learning which examines how people process separate channels for processing verbal and visual material (dual-channels assumption), each channel can process only small amount of material at a time (limited capacity assumption), and meaning learning involves engaging in appropriate cognitive processing (Mayer, 2005, p. 54). 


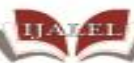

International Journal of Applied Linguistics \& English Literature

ISSN 2200-3592 (Print), ISSN 2200-3452 (Online)

Vol. 1 No. 4; September 2012

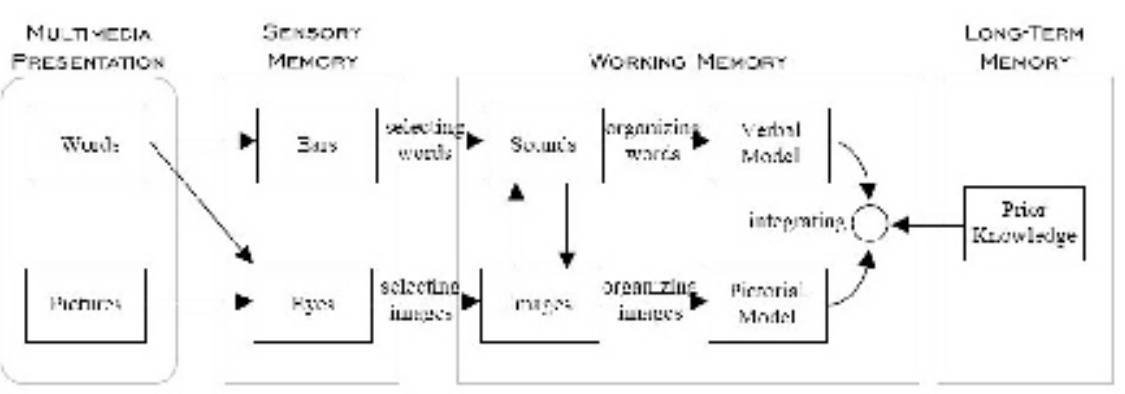

Figure 1. Mayer's cognitive theory of multimedia model (Mayer, 2005, p. 54)

Cognitive load theory could have many implications in the design of learning materials which must, if they are to be effective, keep cognitive load of learners at a minimum during the learning process. In essence, cognitive load theory proposes that since working memory is limited, learners may be bombarded by the information and, if the complexity of their instructional materials is not properly managed, this will result in a cognitive overload. This cognitive overload impairs the schema acquisition, later resulting in lower performance (Sweller, 1988).

To those ends this study has attempted to explore how learners' cognitive orientations can respond to different types of learning materials (i.e., with annotations vs. no annotation). In short, this study intends to investigate the specificity of L2 learners' STM abilities under different conditions of delivery of learning materials.

\subsection{Research questions}

Taking Dual-Coding Theory and Cognitive Load Theory into consideration and referring to the explanations made above, this study is going to discover how visual and verbal abilities of learners come into interaction with the learning of foreign language vocabulary presented through different types of annotations, i.e., no annotation, pictorial and written annotations. Thus, the following general question can be raised:

1. Is there any significant difference in learning L2 vocabulary if learning materials with pictorial and written annotations combined and those without such annotations are delivered to learners with different visual and verbal STM abilities?

It must be noted that the general question can be broken down to a number of corollaries in order to capture the following interactional effects:

1. a. High verbal vs. high visual in relation to both pictorial and written annotation based learning vs. no annotations;

1. b. Low verbal vs. high visual in relation to pictorial and written annotations vs. no annotations;

1. c. Low verbal vs. low visual in relation to both pictorial and written annotation based learning vs. no annotations;

1. d. High verbal vs. low visual in relation to both pictorial and written annotation based learning vs. no annotations.

\subsection{Hypotheses}

In line with CLT, DCT, and the general research question, the following general hypothesis can be formulated:

Learners with different visual and verbal abilities learn learning materials with pictorial and written annotations better than those without such annotations.

\section{Method}

\subsection{Participants}

The participants in this experiment were selected from among those enrolled in EFL classes in an Iranian English institute. They were selected from 12 classes at the same level (i.e., pre-intermediate level). Their age range was between 19-23. Although the minimum large sample size criterion was 25 , and thus for the present study the minimum sample size of $100(25 \times 4=100)$ was sufficient, in order to complete the groups (John Eng, 2003) 161 learners were selected. Three learners were reluctant to learn vocabulary via mobile, so their data were removed from the study leaving a total of 158. Each learner had a different STM ability for processing different LCR (Learning Content Representation) types, that is; LCR with or without pictorial or written annotations (Chen, 
N.-S. et al., 2008); therefore, STM was considered a criterion to divide learners to four groups:

Group 1 (G1): learners with high-visual and high-verbal abilities.

Group 2 (G2): learners with high-visual but low-verbal ability.

Group 3 (G3): learners with both low-visual and low-verbal abilities.

Group 4 (G4): learners with low-visual ability but high-verbal ability. Table 1 represents these four groups.

Table 1. Four groups of learners based on their visual and verbal abilities (adopted from Chen, et al, 2008)

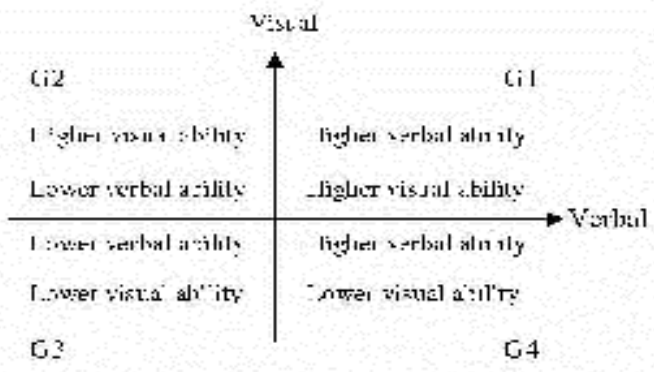

\subsection{Materials}

The materials used in this study were: a) proficiency test, b) vocabulary level test, c) a background questionnaire, d) software package, e) visual and verbal STM tests, and f) English vocabulary recognition and recall tests.

First, to make sure that the participants were all of the same level of proficiency, they were required to participate in Nelson English language test 150 D. The Nelson English language test is a battery consisting of 40 separate tests for each of ten levels from beginners to advanced. Each test consists of 50 items. The tests are designed for a $30(60 \%)$ pass mark. Its reliability was calculated through KR-21 in the pilot study, and it was .82 . The validity was also confirmed by three competent experts in this field

In order to specify the word items for the third phase of the experiment (i.e., learning phase), the word frequency method was adopted. According to Nation and Waring (1997) there should be a clear and sensible goal for vocabulary learning. Frequency information provides a rational basis for making sure that learners get the best return for their vocabulary learning effort. Vocabulary learning frequency lists which take account of range have an important role to play in curriculum design and in setting learning goals. Thus, a vocabulary level test of 50 word items was administered to assess learners' original knowledge of words and to prevent the inclusion of words which learners were familiar with in the learning phase of the experiment. The words for the vocabulary level test were selected from Bauman's General Service List (GSL) which consists of 2284 words. One word from every 40 words was selected, starting from the $40^{\text {th }}$ word (40 2203 more) to $2000^{\text {th }}$ word (15 2000 scenery) (See appendix A). The Bauman's GSL is based on the Brown's corpus which contains 1000,000 words in Bauman's GSL. Beside every word there are two numbers, the first one indicates the order of the word on the list made on the frequency of words in Brown's corpus and the other number indicates the frequency of occurrence of the word in Brown's corpus. Since interchange books are taught in this language institute, the vocabulary lists at the end of the yellow and red interchange books (i.e., introductory and pre-intermediate books) (Hully, Proctor, \& Richards, 2005) were checked too; to discourage the application of words which learners have already learned from these books. When learners completed the vocabulary level test it became clear that nearly all the learners were familiar with words up to the word 'absolute' (1280 62 absolute). Therefore, 20 word items for the third phase of learning were selected from $1500^{\text {th }}$ 'wisdom' (1500 44 wisdom) onward (See appendix B). For each word, the following two types of representation were made:

Type 1- represents the English word, its pronunciation, part of speech and the Persian meaning of the word.

Type 2- represents the materials shown in type 1 plus the pictorial and written annotations (i.e., a sentence).

To enhance the result, all the sentences for type 2 were selected from the Longman Dictionary of Contemporary English. Examples of two different representation types, for the word 'hut' are shown in figure 2. 


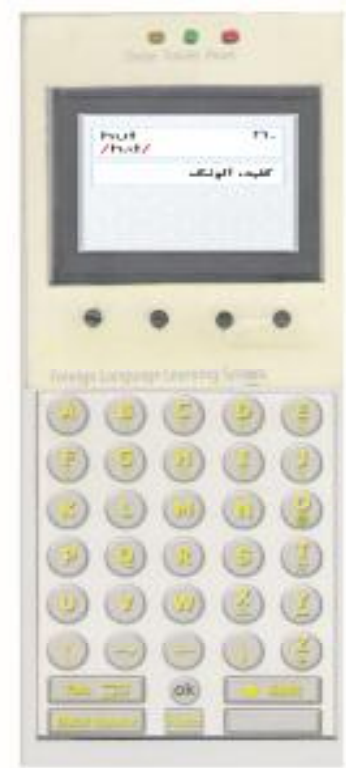

Type 1

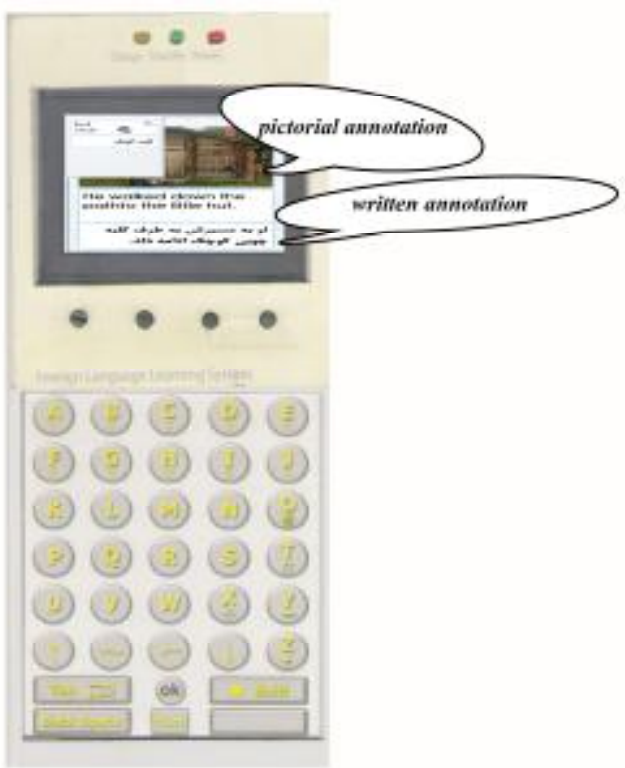

Type 2

Figure 2. Different types of representation

With regard to the background questionnaire, an open-ended questionnaire was prepared to make it possible for learners to express their thoughts and ideas without any limitations. The questions in this questionnaire were those ones which helped the researchers in conducting the subsequent phases of the study. Also, this procedure led to the indirect omission of 3 from the final list of analysis.

Since the objective in this study was to work out a server-side solution and develop user-friendly system presenting the materials in compatibility with PDAs, a software package for conducting STM ability, recognition and recall tests and delivery of materials was designed. The installation procedure, its different parts, and how to use it are all described along with the software CD.

Concerning visual and verbal STM abilities, 40 questions were prepared to test the learners' visual and verbal ability, that is, 20 questions were prepared for testing the learners' visual ability and 20 questions for testing the learners' verbal abilities. The basis of visual and verbal STM tests was the model which was proposed by Chen, C. M., Lee, and Chen, Y. (2005). As reported, personalized service is important on the Internet, especially in web-based learning. Generally, most personalized systems consider learner preferences, interests, and browsing behaviors in providing personalized services. However, learner ability is usually neglected as an important factor in implementing personalization mechanisms. So, they proposed a personalized e-learning system based on Item Response Theory (PEL-IRT), which considers both course material difficulty and learner ability to provide individual learning paths for learners.

Figure 3 illustrates the proposed system architecture, which can be divided into two main parts according to system operation procedures, that is front-end and back-end parts. The front-end part manages communication with learners and records learner behavior. Meanwhile, the back-end part aims to analyze learner ability and select appropriate course materials for learners based on the estimated learner ability. 


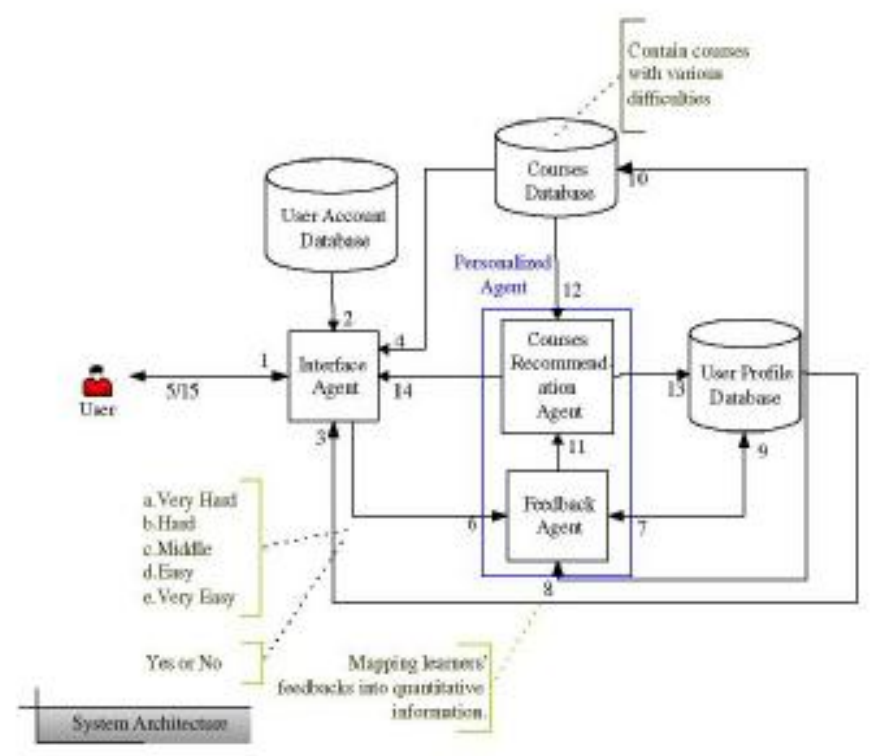

Figure 3. System architecture (Numbers $1 ; 2 ; \ldots ; 15$ indicate the procedure of system operation) (Chen, C. M., Lee, \& Chen, 2005, p. 3)

Finally, since recognition and recall tests are often used to examine learner's vocabulary knowledge (Jones, 2004), 20 recognition questions and 20 recall questions were prepared for testing the learners' vocabulary learning. Although the framework for making recognition and recall tests was like the one extracted from the study was done by Chen, N.-S. et al. (2008), the reliability of our test was calculated through Kuder-Richardson which was .81 .

\section{3. Procedure}

The main procedure for this study consisting four phases took place in the language laboratory of the institute.

Phase I: Introduction. In this phase, all the details and objectives of the experiment were explained. Then, the background questionnaire was distributed among the learners to complete. As mentioned before, this questionnaire was intended to exclude those unwilling to learn vocabulary through the devised method.

Phase II: STM ability test. Each learner was assigned a computer for STM test. First, they took part in a visual STM ability test. Then, they participated in verbal STM test. Each question in these two tests (i.e., verbal and visual) comprised two subparts. Regarding the visual section of the test initially a picture was displayed for eight seconds; then a question was asked about the pictures. The learners were given six seconds to answer the question. Concerning the verbal test, first, a sentence was displayed for eight seconds then a question addressing the sentence was asked; the learners had to answer in six seconds (See appendix C). Afterwards, each learner's answers were recorded with two types of score (i.e., raw score and standard score with a mean of 0 and standard deviation 1). On the basis of their z scores of visual and verbal STM abilities, participants were divided into four groups, with 55 in group1 (G1), 28 in group 2 (G2), 48 in group 3 (G3) and 27 in group 4 (G4). In other words, if participants' visual z scores were higher than zero they were put into group 1 or group 2 , if their visual z scores were lower than 0 they were put into group 3 or 4 . Likewise, if participants' verbal z scores were more than 0 they were put into group 1 or group 4 and if their verbal z scores were lower than 0 they were put into group 2 or group 3. In fact the cut-off score for division of participants into four groups was the 0 of $\mathrm{z}$ score.

Phase III: Learning new vocabularies. In this phase every participant was assigned a PDA to learn 20 new English vocabulary items. All vocabulary items were sent to their PDAs via Bluetooth. Each item was presented to learners for about 120 seconds. As the learners were not able to exit the program from the time they opened the target files until they ended the program, the researcher had full control on all the cell-phones.

In order to counterbalance the effect of the order of representation, a $2 \times 2$ Latin Square (LS) design was used. According to Montgomery (1991), one frequently uses of LS is to counterbalance the various sequences in which the level of an independent variable might take place. In LS, each of the 2 digits (i.e., 1, \& 2) would appear just once in each row and column. Figure 4 shows a $2 \times 2$ Latin Square. 


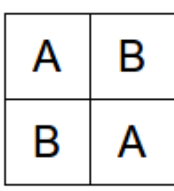

Figure 4. The $2 \times 2$ Latin square

In this research project, the first 10 words were delivered to first participant in type, that is, with no annotation and the last 10 words in type 2 , that is, with pictorial and written annotations. At the same time, the second participant received the first 10 words in type 2 , and the last 10 words in type 1.

Phase IV: Testing phase. After the third phase (i.e., learning phase), learners took part in EVRR (English vocabulary recognition and recall) tests. First, they took part in recognition tests which consisted of 20 multiple-choice questions and then they participated in the recall tests which consisted of 20 questions, too (See appendix D).

\section{Results}

The recognition and recall tests were administered to assess the selected learners' learning outcome in the present study. The main question in this study addressed the effects of content delivery with and without annotations on Iranian learners. Answers to the questions are displayed as follows:

Table 2. Results of the performance of first group of learners on EVRR tests

\begin{tabular}{ccccc}
\hline \multirow{2}{*}{$\begin{array}{c}\text { Group } \\
\text { Differences }\end{array}$} & Mean & \multicolumn{2}{c}{$\begin{array}{c}\text { Paired } \\
\text { Differences }\end{array}$} & \\
\cline { 3 - 4 } & & $\begin{array}{c}\text { 95\% Confidence } \\
\text { Interval of the } \\
\text { Differences }\end{array}$ & Sig. \\
\cline { 2 - 4 } & & Upper & Lower & \\
\hline Recog 1-Recog 2 & -2.43 & -2.13 & -2.43 & $0.000^{*}$ \\
\hline Recall 1-Recall 2 & -2.36 & -2.03 & -2.36 & $0.000^{*}$ \\
\hline Ave1-Ave4 & -2.40 & -2.16 & -2.40 & $0.000^{*}$ \\
\hline$p .<0.005$ & & & & \\
\hline
\end{tabular}

Note. Recog. $=$ recognition score, $\&$ Ave.= average score

As for the first group of learners (high visual + high verbal), the analysis shows a mean of 2.2 on recognition and 1.02 on recall test for no annotation materials. In a somewhat salient manner, the results of the two tests for the same group rise to around a mean of 4.64 on recognition and a mean of 4.00 for materials with pictorial and written annotations. This shows that annotations of this kind have some bearing on the learners' short-term memory. Regarding Table 2, the inferential statistics also revealed that the differences between no annotation vs. written and pictorial annotations remain significant (Sig.: 0.000).

Table 3. Results of the performance of second group of learners on EVRR tests

\begin{tabular}{ccccc}
\hline & \multicolumn{3}{c}{ Paired } \\
\cline { 3 - 4 } Group & Mean & & \\
\cline { 3 - 4 } Differences & & $\begin{array}{c}\text { 95\% Confidence } \\
\text { Interval of the } \\
\end{array}$ & Sig. \\
& & Differences & \\
\cline { 3 - 4 } & & Upper & Lower & \\
\hline Recog 1-Recog 2 & -1.46 & -0.90 & -2.02 & $0.000^{*}$ \\
\hline Recall 1-Recall 2 & -0.82 & -0.38 & -1.25 & $0.001^{*}$ \\
\hline Ave 1-Ave 2 & -1.14 & -0.73 & -1.55 & $0.000^{*}$ \\
\hline
\end{tabular}

p. $<0.005$

Note. Recog.= recognition score, $\&$ Ave. $=$ average score 
International Journal of Applied Linguistics \& English Literature

ISSN 2200-3592 (Print), ISSN 2200-3452 (Online)

Vol. 1 No. 4; September 2012

The second group comprising high-visual and low-verbal underperformed on the two tests with no annotation (means of 1.82 and 1.00 for recognition and recall tests, respectively), compared with written and pictorial annotation types (means of 3.29 and 1.82 for recognition and recall tests, respectively). This result is also shown to be significantly different (Sig.: .000 \& Sig.: 0.001 for recognition \& recall teats, respectively).

Table 4. Results of the performance of third group of learners on EVRR tests

\begin{tabular}{|c|c|c|c|c|}
\hline \multirow{3}{*}{$\begin{array}{c}\text { Group } \\
\text { Differences }\end{array}$} & \multirow{3}{*}{ Mean } & $\begin{array}{r}\mathrm{P} \\
\text { Diff }\end{array}$ & $\begin{array}{l}\text { ed } \\
\text { ences }\end{array}$ & \multirow{3}{*}{ Sig. } \\
\hline & & \multicolumn{2}{|c|}{$\begin{array}{l}95 \% \text { Confidence } \\
\text { Interval of the } \\
\text { Differences }\end{array}$} & \\
\hline & & Upper & Lower & \\
\hline Recog 1-Recog 2 & 2.39 & 2.68 & 2.11 & $0.000 *$ \\
\hline Recall 1-Recall 2 & 2.14 & 2.48 & 1.80 & $0.000 *$ \\
\hline Ave 1-Ave 2 & 2.27 & 2.51 & 2.02 & $0.000 *$ \\
\hline
\end{tabular}

Note. Recog.= recognition score, \& Ave.= average score

For group three in which participants are low-visual and low-verbal, the story diverges, their performance on the no annotation types outweighing their performance obtained on with annotation type (means of 3.83 \& 3.31 , respectively on recognition and recall tests). The inferential statistics analysis also showed that the group's performances on no annotation type vs. written and pictorial annotation type were significantly different (Sig.: $0.000)$.

Table 5. Results of the performance of fourth group of learners on EVRR tests

\begin{tabular}{|c|c|c|c|c|}
\hline \multirow{3}{*}{$\begin{array}{c}\text { Group } \\
\text { Differences }\end{array}$} & \multirow{3}{*}{ Mean } & \multicolumn{2}{|c|}{$\begin{array}{c}\text { Paired } \\
\text { Differences }\end{array}$} & \multirow{3}{*}{ Sig. } \\
\hline & & \multicolumn{2}{|c|}{$\begin{array}{c}95 \% \text { Confidence } \\
\text { Interval of the } \\
\text { Differences }\end{array}$} & \\
\hline & & Upper & Lower & \\
\hline Recog 1-Recog 2 & -1.77 & -1.42 & -2.13 & $0.000 *$ \\
\hline Recall 1-Recall 2 & -2.11 & -1.74 & -2.48 & $0.000 *$ \\
\hline Ave 1-Ave 2 & -1.94 & -1.65 & -2.23 & $0.000 *$ \\
\hline
\end{tabular}

Note. Recog.= recognition score, \& Ave.= average score

Group four (low-visual and high-verbal) performed significantly better (Sig.: 0.000) on annotation type than on no annotation type (means of 2.22 and 1.61 on recognition and recall tests, respectively for written and pictorial annotations type). 
International Journal of Applied Linguistics \& English Literature

ISSN 2200-3592 (Print), ISSN 2200-3452 (Online)

Vol. 1 No. 4; September 2012

Table 5. Descriptive statistics: Recognition score, recall score, \& average score of four groups

\begin{tabular}{|c|c|c|c|c|c|c|c|c|c|}
\hline \multirow{2}{*}{ Group } & \multirow{2}{*}{$\begin{array}{c}\text { Number } \\
\text { of } \\
\text { subjects }\end{array}$} & \multirow{2}{*}{ Age } & \multirow{2}{*}{ Type } & \multicolumn{2}{|c|}{ Recognition Score } & \multicolumn{2}{|c|}{ Recall Score } & \multicolumn{2}{|c|}{ Average Score } \\
\hline & & & & Mean & Std. Error & Mean & Std. Error & Mean & Std. Error \\
\hline \multirow{2}{*}{1} & \multirow{2}{*}{55} & \multirow{2}{*}{21.5} & 1 & 2.2 & 0.14 & 1.02 & 0.12 & 1.60 & 0.10 \\
\hline & & & 2 & 4.64 & 0.09 & 3.38 & 0.14 & 4.00 & 0.10 \\
\hline \multirow{2}{*}{2} & \multirow{2}{*}{28} & \multirow{2}{*}{21.53} & 1 & 1.82 & 0.19 & 1 & 0.15 & 1.41 & 0.14 \\
\hline & & & 2 & 3.29 & 0.17 & 1.82 & 0.15 & 2.55 & 0.12 \\
\hline \multirow{2}{*}{3} & \multirow{2}{*}{48} & \multirow{2}{*}{21.22} & 1 & 3.83 & 0.134 & 2.79 & 0.15 & 3.3 & 0.12 \\
\hline & & & 2 & 1.44 & 0.13 & 0.65 & 0.10 & 1.04 & 0.09 \\
\hline \multirow{2}{*}{4} & \multirow{2}{*}{27} & \multirow{2}{*}{21.18} & 1 & 2.22 & 0.14 & 1 & 0.16 & 1.61 & 0.12 \\
\hline & & & 2 & 4 & 0.16 & 3.11 & 0.15 & 3.55 & 0.142 \\
\hline
\end{tabular}

p. $<0.005$

Note. Recog., Recall, \& Ave. refers to recognition, recall, \& average score respectively.

What is clear from this finding is as follows:

- Learners with both high-visual ability and high-verbal ability, learn learning materials with written and pictorial annotations better than the types without annotations.

- The delivery of materials with pictorial and written annotations to learners with high-visual but low-verbal ability results in better vocabulary learning.

- The delivery of content without annotation to learners with both low-visual and low-verbal abilities results in better vocabulary learning than delivery of the type with pictorial and written annotations.

- Learners with low-visual ability but high-verbal ability learn materials with written and pictorial annotations better than those without such annotations.

\section{Conclusion and Discussion}

The results reached in this study show that although learners with high-visual ability and/or high-verbal ability, learn materials with annotations better than those without, delivery of learning materials without annotation to learners with both low-visual and low-verbal abilities results in better vocabulary learning than delivery of the type with annotations. Since finding of the present study showing that the low-verbal and low-visual learners can take advantage of the basic materials with no annotation and this substantiates the modality specificity of STM further. The finding has already been explained by Sweller (1994). He maintains that such learners are likely to get overwhelmed in the presence of multimodal representations of contents. This explanation, referred to as CLT (Sweller, 1994), argues that some learners with limited processing capacity, say low verbal/visual, tend to avoid the information overload by relying on the basic and single dimension of the content. However, the finding sounds a bit counterproductive if judged against the Dual-Coding theory suggested by Paivio (1986). This latter theory upholds the idea that different modalities combined together present an optimal condition for accommodating more channels of learning simultaneously, thus increasing the likelihood of learning such materials.

Also, the results of this study support the results Chen N.-S. et al. (2008) reported, where it was demonstrated that that learners with high-verbal and high-visual abilities benefit from learning materials with written and pictorial annotations. On the other hand, learners with low-verbal and low-visual abilities learn vocabulary items which are delivered to them without annotation better than those with. Likewise, learners with high-verbal but low-visual abilities and learners with high-visual but low-verbal ability perform well on both recognition and recall tests of leaning material with both written and pictorial annotations.

Regarding to the potential of mobile devices and their affinity with the realm of teaching and learning vocabulary, it seems indispensable to go beyond that and employ them in teaching and learning other skills and sub-skills of 
language. Although, in this study such matters as the level of the participants and their PLP were taken into consideration, there were still a lot of issues, theories, and rules that could not be ignored. Likewise, with multimedia as the salient characteristic of mobile devices, incorporating instructional strategies and processes to enhance the principles of cognitive psychology in the design phases seems unavoidable (Kumar, 2004).

On the whole, although the use of wireless and mobile devices are gradually increasing in the realm of pedagogy, a major limitation in the application of cell-phone for EFL learning is that in the early phases it cannot replace the common daily classes and it demands the proper conditions that at times must be met to set the ground for implementation; on the other hand, at the primary phases they could be exploited to support the learners' out-of-class practice or to be used as one of the elements of blended courses (i.e., traditional and modern manner of content delivery) (Kennedy \& Levy, 2008).

With increased popular access to information and knowledge anywhere and anytime, the role of education perhaps especially formal education is challenged and the relationships between education, society and technology are now more dynamic than ever (Traxler, 2007). It seems suitable to go beyond using such technology in the limited environment and in the case of limited number of learners to see if purist case for mobile learning includes the idea that m-learning will support a wide variety of conceptions of teaching exists in the $p$ sense of the word (Traxler, 2007). Thanks to the existence of Internet connection facilities such as GPRS and Wi-Fi, it is possible to do conduct the same studies with other wireless devices as laptop computers which are treated as mobile.

\section{References}

Atkinson, R. C., \& Shiffrin, R. M. (1968). Human memory: A proposed system and its control processes. In K.W. Spence \& J. T. Spence (Eds.), The Psychology of Learning and Motivation, 2, 89-195.

Bauman (1995). About the GSL. Retrieved March 20, 2009 from http://www.jbauman.com/aboutgsl.html

Brown, J. D. (1988). Understanding research in second language learning. Cambridge University Press.

Bull, S., \& Kukulska-Hulme, A. (2009). Theory- based support for mobile language learning: Noticing and recording. $i J I M, 3(2), 12-18$.

Chen, C. M., Lee, H. M., \& Chen, Y. (2005). Personalized e-learning system using item response theory. Computers and Education, 44(3), 237-255.

Chen, Ch.-M., \& Chung, Ch.-J. (2008). Personalized mobile English vocabulary learning system based on item-response theory and learning memory cycle [Abstract]. Journal of Computer and Education, 51 (2), 624-645.

Chen, Ch.-M., \& Hsu, sh.-H. (2008). Personalized mobile learning system for supportive effective English learning. Educational Technology and Society, 11 (3), 153-180.

Chen, N.-S., Hsieh, sh.-W., \& Kinshuk. (2008). The effects of short-term memory and content representation type on mobile language learning. Journal of Learning and Technology, 12, 93-113.

Chun, D. M., \& Plass, J. L. (1996). Effects of multimedia annotations on vocabulary acquisition [Abstract]. The Modern Language Journal, 80, 183-198.

Coe, N., \& Fowler, W. S. (1976). Nelson English Language Tests. London: Butler and Tanner Ltd.

Conacher, J. (2009, November). Using technologies in learning, teaching and research: Challenges and opportunities for the language Profession. Paper presented at the conference of Technology Enhanced Language Teaching and Learning, London, Vernon.

Cui, G., \& Wang, Sh. (2008). Adopting cell phones in EFL teaching and learning. Journal of Educational Technology Development and Exchange, 1, 69-80.

Ellis, N.C. (1996). Working memory in the acquisition of vocabulary and syntax: Putting language in good order. The Quarterly Journal of Experimental Psychology, 49(1), 234-250.

Entekhabi, N., Haghshenas, A. M., \& Samei, H. (2003). Millennium English-Persian dictionary. Tehran: Farhang Moaser Publishers. 
International Journal of Applied Linguistics \& English Literature

ISSN 2200-3592 (Print), ISSN 2200-3452 (Online)

Vol. 1 No. 4; September 2012

Greffe, Ch., Linden, M.V., Majerus, S., \& Poncelet, M. (2005). Relations between vocabulary development and verbal short-term memory: The relative importance of short-term memory for serial order and item information. Journal of Experimental Child Psychology 93 (2), 95-119.

Gupta, P., \& Whinney, B. M. (1997). Vocabulary acquisition and verbal short-term memory: computational and neural bases. Brain and Language, 59, 267-333.

Hopper, H. U., Joiner, R., Milrad, M., \& Shrples, M. (2003). Guest editorial: wireless and mobile technology in education. Journal of Computer Assisted Learning, (19), 255-259.

Hully, J., Proctor, S., \& Richards, J. C., (2005). New Interchange ( $3^{\text {rd }}$ ed.). Cambridge University Press.

John Eng, M. D. (2003). Sample size estimation: how many individuals should be studied? Radiology, 227, 309-313.

Jones, L., (2004). Testing L2 vocabulary recognition and recall. Learning and Technology, 8(3), 122-143.

Kennedy, C. \& Levy, M. (2008). Using SMS to support beginners' language learning. Recall,20 (3), 315-330.

Klas, W. \& Zaharieva, M. (2004). Mobilearn: An open approach for structuring content for mobile learning environments (pp. 114-124). Berlin: Springer.

Kumar, M. (2004). A critical discourse in multimedia design. E-Journal of Instructional Science and Technology, $7(2), 1-8$.

Longman dictionary of contemporary English (4 ${ }^{\text {th }}$ ed.). England: Pearson Education Limited.

Mayer, R. E., 1979. Can advance organizers influence meaningful learning? Review of Educational Research, 49(2), 371-383.

Mayer R.E. (2003). Elements of a science of e-learning. Educational Computing Research, 29 (3), $297-313$.

Mayer, R. E., Sobko, K., \& Mautone, P. D. (2003). Social cues in multimedia learning: Role of speaker's voice. Journal of Educational Psychology, 95, 419-425.

Mayer, R. E. (Ed.) (2005). The Cambridge handbook of multimedia learning. Cambridge University Press.

Rate of influencing cell phones will reach to 61 percent at the end of the year 2008. Retrieved February 12, 2010 from http://www.medianews.ir

Montgomery, D. C. (1991). Design and analysis of the experiments. NY: John Wiley \& Sons.

Nation, P. \& Waring, R. (1997). Vocabulary size, text coverage and word lists. Retrieved March 27, 2010, from http://www.fltr.ucl.ac.be/fltr/GERM/ETAN/bibs/vocab/cup.html

Paivio, A. (1986). Mental representations: A dual coding approach. UK: Oxford University Press.

Pieri, M. \& Diamantini, D. (2008). From e-learning to mobile learning: New opportunities. International Journal of Knowledge and Learning, 4 (2-3), 176-188.

Richards, J. C., \& Schmidt, R. (2002). Dictionary of language and applied linguistics (3 ${ }^{\text {rd }}$ ed.). England: A Pearson Education Book.

Reis, J. C., Bonacian, R. \& Martins, M. C. (2009). Using multimedia in the mobile collaborative learning. Research, Reflection, and Innovation in Integrating ICT in Education, 869-873.

Sharples, M. (2000). The design of personal mobile technologies for lifelong learning. Computer and Education, 34 (4), 177-193.

Sweller, J. (1988) Cognitive load during Problem Solving: Effects on learning. Cognitive Science, 12, 257-285.

Traxler, J. (2007). Defining, Discussing, and Evaluating Mobile Learning. International Review of Research in Open and Distance Learning, 8(2), 1-12.

United Nations [UN], 2010. 67 Percent of people have cell phones. Retrieved March 25, 2010 from http://www.stltoday.com/stltoday/news/stories.nfs/world/story. 
International Journal of Applied Linguistics \& English Literature

ISSN 2200-3592 (Print), ISSN 2200-3452 (Online)

Vol. 1 No. 4; September 2012

Appendix A - Vocubulary l.crel Text

Vame:

Ape:

Dale:

\begin{tabular}{|c|c|c|c|c|c|}
\hline \multicolumn{6}{|c|}{ Basic: Linglish Yocabulary Test } \\
\hline 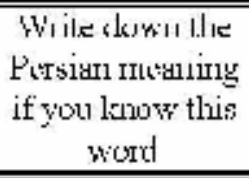 & $\begin{array}{c}\text { M:1 k 'X' il you } \\
\text { domit know ل لs: } \\
\text { mening of this } \\
\text { word }\end{array}$ & Linglish words & 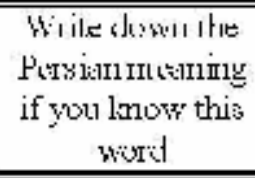 & $\begin{array}{l}\text { Mailk ' } \mathrm{K} \text { ' il'you } \\
\text { doml know lic } \\
\text { meaning of this } \\
\text { nurd }\end{array}$ & Linglish words \\
\hline & & invile & & & Illore \\
\hline & & seet & & & tind \\
\hline & & suite & & & write \\
\hline & & smins & & & lowils: \\
\hline & & 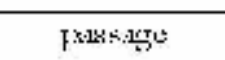 & & & lime \\
\hline & & lyain & & & repot. \\
\hline & & absoluts: & & & dirtect \\
\hline & & atford & & & locly \\
\hline & & noise & & & thus \\
\hline & & solve & & & death \\
\hline & & lyust. & & & mat \\
\hline & & iilsterlerence & & & IItokicin \\
\hline & & fort.11าate & & & islancl \\
\hline & & coid & & & Linglislı \\
\hline & & insect & & & เmploy \\
\hline & & sugar & & & sppoutunity \\
\hline & & eorystrivinl & & & touslı \\
\hline & & crowin & & & current. \\
\hline & & eoripprnion & & & prọ̣css \\
\hline & & لsılruetive & & & buinin \\
\hline & & Inunch & & & engines| \\
\hline & & resign & & & shomlcler \\
\hline & & Wireck & & & testroy \\
\hline & & extielde & & & silick \\
\hline & & scenely & & & axthe it \\
\hline
\end{tabular}


International Journal of Applied Linguistics \& English Literature

ISSN 2200-3592 (Print), ISSN 2200-3452 (Online)

Vol. 1 No. 4; September 2012

Appendix B - 20 word items for the third phase

\begin{tabular}{|c|c|c|c|}
\hline Order & Frequency & Word & Part of speech \\
\hline 1516 & 43 & anxiety & $\mathrm{n}$. \\
\hline 1519 & 42 & sacred & Adj. \\
\hline 1583 & 38 & flame & $\mathrm{n}$. \\
\hline 1628 & 35 & adventure & n. \\
\hline 1638 & 35 & melt & $\mathrm{v}$. \\
\hline 1641 & 35 & bury & $\mathrm{v}$. \\
\hline 1797 & 26 & immense & Adj. \\
\hline 1812 & 25 & feather & $\mathrm{n}$. \\
\hline 1840 & 23 & bunch & n. \\
\hline 1855 & 23 & decay & v. \\
\hline 1875 & 22 & explode & v. \\
\hline 1929 & 19 & hut & n. \\
\hline 2061 & 12 & patriotic & Adj. \\
\hline 2080 & 12 & castle & n. \\
\hline 2101 & 11 & applaud & $\mathrm{v}$. \\
\hline 2119 & 10 & beast & n. \\
\hline 2192 & 7 & paw & n. \\
\hline 2198 & 6 & bribe & $\mathrm{v}$ \\
\hline 2278 & 0 & oar & n. \\
\hline 2283 & 0 & beak & $\mathrm{n}$. \\
\hline
\end{tabular}


International Journal of Applied Linguistics \& English Literature

ISSN 2200-3592 (Print), ISSN 2200-3452 (Online)

Vol. 1 No. 4; September 2012

\section{Appendix C - Sample of questionnaire}

In the name of God

Background questionnaire

First name:

Last name:

Age:

code:

How long have you used cell-phone?

How much do you use your cell-phone during a day?

How much do you tend to use cell-phone for learning English?

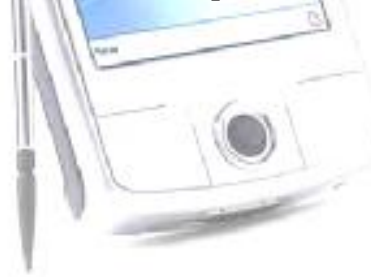

What is your opinion about the future of using cell-phone in learning English? 


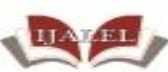

International Journal of Applied Linguistics \& English Literature

ISSN 2200-3592 (Print), ISSN 2200-3452 (Online)

Vol. 1 No. 4; September 2012

Appendix D - Sample of visual and verbal STM tests
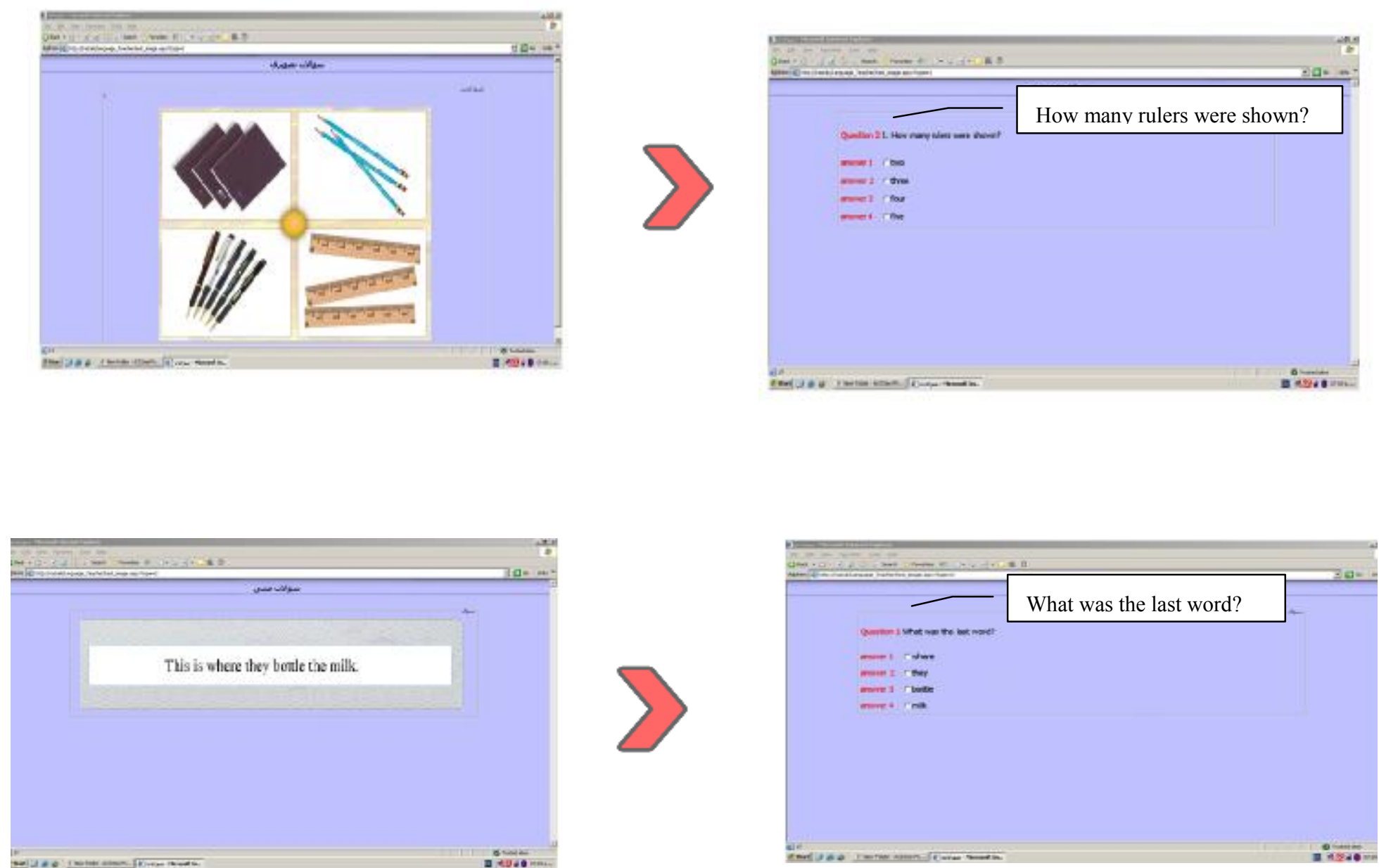
International Journal of Applied Linguistics \& English Literature

ISSN 2200-3592 (Print), ISSN 2200-3452 (Online)

Vol. 1 No. 4; September 2012

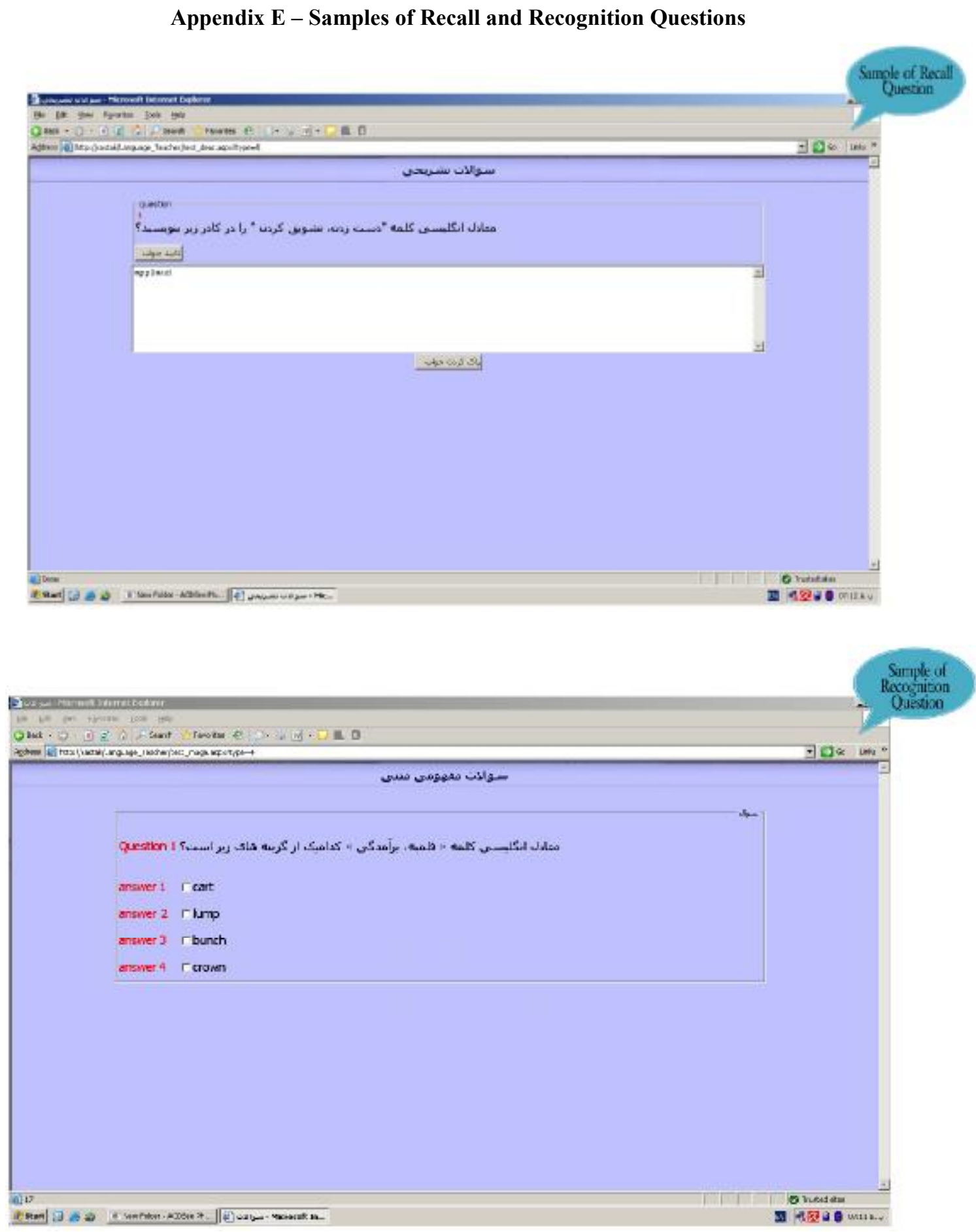

